\title{
MĚŘENÍ ČINITELE ZVUKOVÉ POHLTIVOSTI V IMPEDANČNÍ TRUBICI
}

\author{
MEASUREMENT OF SOUND ABSORPTION COEFFICIENT IN \\ IMPEDANCE TUBE
}

\author{
David Jun ${ }^{*}, 1$, Ondřej Nespěšný ${ }^{1}$
}

*David.Jun@vut.cz

${ }^{1}$ Vysoké učení technické v Brně, Fakulta stavební, Veveří 331/95, 60200 Brno

\begin{abstract}
Abstrakt
Činitel zvukové pohltivosti je jednou ze základních veličin popisujících akustické chování materiálů a konstrukcí určených pro použití v prostorové akustice. Tento př́spěvek nejprve popisuje stručný přehled technik pro měření činitele zvukové pohltivosti. Zvláštní pozornost je věnovaná skupině metod využívající impedanční trubici, často také nazývanou Kundtova trubice. Následuje představení měření metodou přenosové funkce a vlastního prototypu impedanční trubice zahrnujícího jak hardwarovou sestavu, tak softwarovou implementaci měření.
\end{abstract}

\section{Klíčová slova}

prostorová akustika, zvuková pohltivost, impedanční trubice, metoda přenosové funkce

\begin{abstract}
The sound absorption coefficient is one of the most common quantities describing the acoustic behaviour of materials and structures intended for use in room acoustics. This contribution first shows a brief overview of techniques for measuring sound absorption coefficient. Special attention is paid to the impedance tube (often called Kundt tube) group of methods. The following is an introduction to the measurement of the transfer-function method and to a developed impedance tube prototype, including both the hardware assembly and the software implementation of the measurement.
\end{abstract}

Key words

room acoustics, sound absorption, impedance tube, transfer-function method

\section{1 ÚVOD}

Činitel zvukové pohltivosti je stále nejpoužívanější veličinou při výpočtech v prostorové akustice. O zavedení této veličiny se zasloužil již před více než sto lety W. C. Sabine [1], který se zabýval měřením této veličiny vyhodnocováním dozvuků v místnostech. Dnes hojně používaná dozvuková metoda popsaná v normě ČSN EN ISO 354 [2] vychází z původních Sabinových poznatků, nicméně využívá množství tehdy nedostupných technických možností. Jedná se o měření chrakteristické snahou o dosažení difuzního akustického pole v měřící místnosti, a tedy náhodného směru dopadu zvuku na měřený vzorek. Tato situace je obecně bližší té v běžných místnostech, nicméně operuje s poměrně vysokou nejistotou měření vycházející z obtížně dosažitelného ideálně difuzního akustického pole. Tyto limity jsou dále zvýrazněny pod hranicí takzvané Schroederovy frekvence empiricky vymezující použitelnost statistické, popřípadě vlnové akustiky. Z této nejistoty vychází i její omezená využitelnost při ověřování fyzikálních modelů predikujících akustické chování materiálů a konstrukcí.

Tento nedostatek se daří překlenout druhé skupině metod využívajících impedanční trubice. Jedná se o metody umožňující měřit jak akustickou impedanci, tak i činitel zvukové pohltivosti. V tomto případě však pro kolmý dopad vln. Díky této jasné určenosti okrajových podmínek a podmínek šíření zvuku jsou tyto metody hojně využívány pro validaci materiálových a jiných teoretických modelů. Další charakteristikou této metody je použití řádově menších vzorků než v případě měření v dozvukové místnosti. Tab. 1 shrnuje základní rozdíly mezi oběma skupinami metod. 
Tab. 1 Srovnání metod pro měření činitele zvukové pohltivosti $\alpha[-]$.

\begin{tabular}{|c|c|c|}
\hline Vlastnost & Dozvuková místnost & Impedanční trubice \\
\hline Činitel zvukové pohltivosti & Sabinův $\alpha_{S}[-]$ & pro kolmý dopad vln $\alpha_{n}[-]$ \\
\hline Platná ČSN & ČSN EN ISO 354 [2] & $\begin{array}{l}\text { ČSN ISO 10534-1 [3], } \\
\text { ČSN ISO 10534-2 [4] }\end{array}$ \\
\hline Hlavní + & $\begin{array}{l}\text { měření pro náhodný dopad, jednoduchost, } \\
\text { velký rozsah měřených frekvencí }\end{array}$ & $\begin{array}{l}\text { malé vzorky, definovaný úhel } \\
\text { dopadu, vyšší reprodukovatelnost }\end{array}$ \\
\hline Hlavní - & velký vzorek, nižší reprodukovatelnost & $\begin{array}{c}\text { pouze kolmý dopad, malé vzorky, } \\
\text { nižší frekvenční rozsah }\end{array}$ \\
\hline
\end{tabular}

Cílem zde prezentovaného výzkumu je vytvoření prototypu impedanční trubice. Tato trubice má umožnit měření činitele zvukové pohltivosti různých typů akustických rezonátorů určených pro tlumení v nejnižších oktávách slyšitelného spektra. Samotné měření bude v dalším výzkumu sloužit mimo jiné k validaci numerického modelu, čemuž by měla být uzpůsobena geometrie, sběr dat a provádění variantních měření pro získání uceleného datasetu.

\section{POPIS SOUČASNÉHO STAVU}

August Kundt popsal již v roce 1866 přístroj pro měření rychlosti zvuku ve vzduchu a jiných plynech [5]. Podobností se současnými impedančními trubicemi není mnoho a tou hlavní zůstává fakt, že se vyhodnocuje stojaté vlnění uvnitř trubice, samotné technické provedení však přirozeně doznalo od té doby značných změn. V současnosti se setkáváme se dvěma základními variantami metody impedanční trubice, které obě umožňují měřit jak činitel zvukové pohltivosti, tak akustickou impedanci na povrchu zkoumaného vzorku.

První z metod je takzvaná metoda poměru stojaté vlny. Schéma trubice pro tento typ měření je zobrazeno na Obr. 1. Tato metoda je starší, jednodušší, robustnější a zároveň výrazně pomalejší než varianta popsaná níže. Zvýšená doba měření je dána především tím, že měření probíhá zvlášt' pro jednotlivé frekvence, kdy se pro každou z nich hledá poloha a amplituda minima a maxima akustického tlaku. Díky vyšší robustnosti se však tato metoda

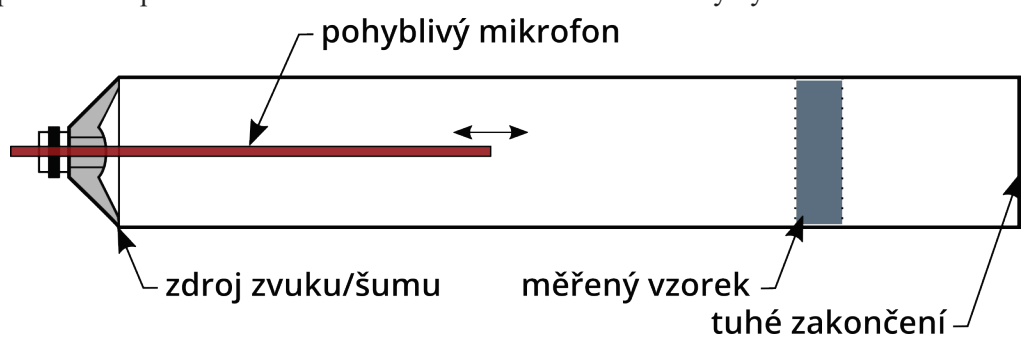

Obr. 1 Schéma impedanční trubice, metoda poměru stojaté vlny.

jeví i nadále vhodná pro kontrolu výsledků získaných druhou metodou [6].

Druhá z metod se nazývá metoda přenosové funkce nebo také metoda dvou mikrofonů (two-microphone method) a obecné schéma používané trubice je znázorněno na Obr. 2. Jak je zjevné z druhého používaného názvu, tato metoda využívá současné nahrávání dvou a více mikrofonů při excitování trubice měřícím signálem, aby následně z nahrávek a umístění mikrofonů vůči vzorku bylo možné vypočítat impedanci na povrchu vzorku nebo činitel zvukové pohltivosti. Tato metoda je výhodná především díky své rychlosti a zároveň vysokému

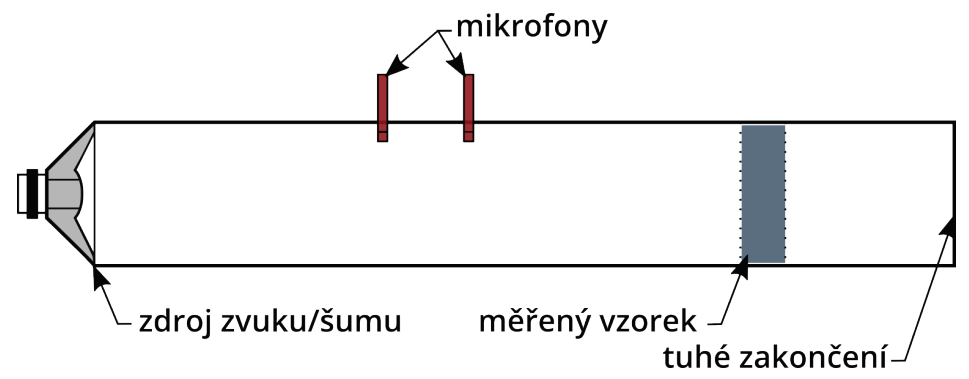

Obr. 2 Schéma impedanční trubice, metoda přenosové funkce. 
frekvenčnímu rozlišení výsledků, což vychází z vlastností diskrétní Fourierovy transformace. Díky současnému stavu technologií, zpracování digitálního signálu a zejména díky objevení algoritmu rychlé Fourierovy transformace je možné vyhodnocení provádět ve frekvenční doméně téměř v reálném čase spolu se samotným měřením. Kvalita výsledků je pak závislá především na hardwarové straně: na zpracování samotné trubice, na použitých mikrofonech a AD a DA převodnících. Následující kapitoly se zabývají právě touto metodou a vývojem vlastní měřící sestavy.

\section{METODA PřENOSOVÉ FUNKCE}

Pro vyhodnocení činitele zvukové pohltivosti dle ČSN ISO 10534-2 [4] je třeba nejprve zavést několik veličin:

- $\quad p$ je Fourierova transformace záznamu akustického tlaku. Vzhledem k digitálnímu záznamu se jedná o vektor tvořený bezrozměrnými komplexními čísly.

- $S_{12}$ se nazývá křížové spektrum a jedná se o produkt násobení $p_{2}$ a komplexního konjugátu $p_{1}$. Dolní indexy zde rozlišují umístění mikrofonů.

- $\mathrm{H}_{12}$ se nazývá přenosová funkce a je možné ji vypočítat např́ílad jako podíl $S_{12} / S_{11}$ nebo $S_{22} / S_{21}$.

- $H_{c}$ se nazývá kalibrační faktor, který slouží ke korekci rozdílu fáze a amplitudy mezi mikrofony

Prvním z cílů vyhodnocení je získání přenosové funkce $H_{12}$ ze záznamu akustického tlaku. $\mathrm{K}$ tomu slouží následující postup:

- převedení záznamu zvuku do frekvenční domény pomocí Fourierovy transformace, čímž je získán $p$. Díky převodu do frekvenční domény hned v počátku je možné téměř celé další vyhodnocení provést pomocí jednoduchého a výpočetně nenáročného násobení a dělení vektorů.

- Výpočet krrížového spektra podle vztahu

$$
S_{12}=p_{2} \cdot \operatorname{conj}\left(p_{1}\right)
$$

- Výpočet autospektra podle vztahu

$$
S_{11}=p_{1} \cdot \operatorname{conj}\left(p_{1}\right)
$$

- Výpočet přenosové funkce podle vztahu

$$
H_{12}=\frac{S_{12}}{S_{11}}
$$

Tento postup se opakuje při každém vyhodnocení přenosové funkce.

Před měřením je třeba vyhodnotit kalibrační faktor $H_{c}$. Ten je možné použít na libovolný počet následujících měření za předpokladu, že se výrazně nemění okrajové podmínky (teplota a relativní vlhkost) a že nedošlo ke změně nastavení zdroje zvuku nebo záznamového zařízení. Pro kalibraci trubice je třeba použít měření vysoce pohltivého vzorku. Kalibrační faktor je možné získat ze vztahu

$$
H_{c}=\sqrt{\frac{H_{12}^{I}}{H_{21}^{I I}}}
$$

kde $H_{12}^{I}$ představuje přenosovou funkci získanou při měření v běžné konfiguraci mikrofonů a $H_{21}^{I I}$ představuje obdobně získanou přenosovou funkci, nicméně měřenou při obrácené konfiguraci mikrofonů.

Následná měření se korigují tímto kalibračním faktorem podle vztahu

$$
H_{12}=\frac{\widehat{H_{12}}}{H_{C}}
$$

kde $\widehat{H_{12}}$ představuje nekorigovanou přenosovou funkci a $H_{12}$ přenosovou funkci po korekci. Z této korigované se následně vypočítá činitel odrazu $r[-]$ dle vztahu

$$
r=\frac{H_{12}-H_{I}}{H_{R}-H_{12}} e^{2 j k_{0} x_{1}}
$$

kde $H_{I}$ představuje přenosovou funkci pouze pro dopadající vlnu a $H_{R}$ představuje přenosovou funkci pouze pro odraženou vlnu. Obě tyto veličiny je možné spočítat dle přílohy D normy ČSN ISO 10534-2 [4]z okrajových podmínek měření a geometrie trubice. Činitel zvukové pohltivosti pro kolmý dopad vln $\alpha_{n}$ se na závěr vypočítá za vztahu

$$
\alpha_{n}=1-|r|^{2}
$$




\section{PROTOTYP MĚŘÍCÍ SESTAVY}

Pro účely této práce byl vyvinut prototyp měřící sestavy zahrnující vlastní hardwarové i softwarové řešení měření.

\section{Hardware}

Prototyp impedanční trubice prezentovaný $\mathrm{v}$ tomto př́spěvku byl sestaven výhradně z obecně dostupných hardwarových komponent. Základní konstrukce trubice byla vyrobena z březové překližky tloušt'ky $18 \mathrm{~mm}$, spoje jsou převážně lepené.

Samotná trubice se skládá ze tří částí:

- Č́st pro umístění vzorku

- Střední část

- Reproduktorová část

Jednotlivé části jsou vyobrazeny na Obr. 3. Část pro umístění vzorku prodlužuje střední část a obsahuje posuvnou zadní stěnu představující tuhé zakončení trubice. Ve střední části se nachází dvojice mikrofonů a izolant na straně reproduktoru, který eliminuje příčné rezonance v trubici. Reproduktorovou část představuje uzavřená dutina obsahující reproduktor namířený směrem ke střední části. Jednotlivé části jsou k sobě rozebíratelně připojeny šrouby.

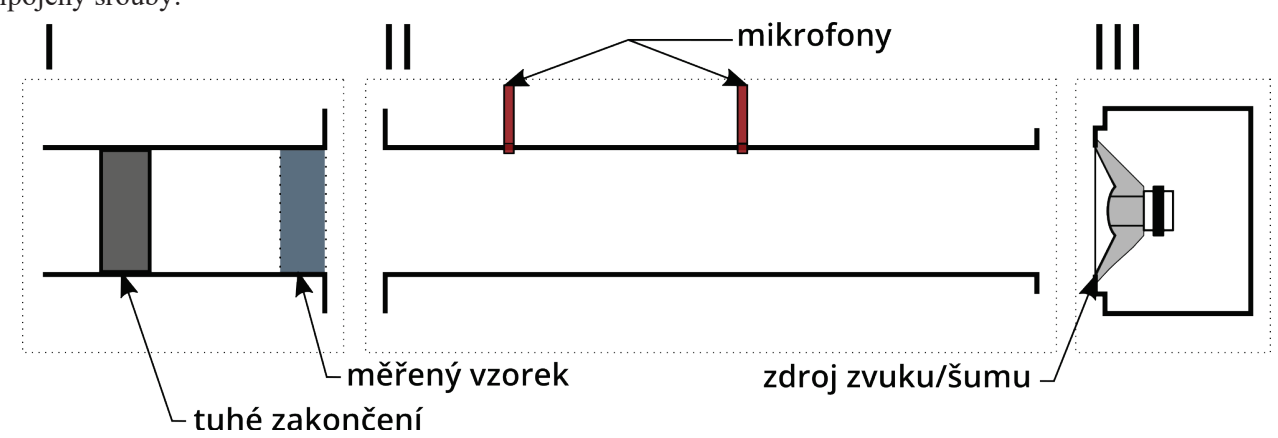

Obr. 3 Součásti impedanční trubice. I - Část pro umístění vzorku, II - Střední část, III - Reproduktorová část.

Z hlediska použité měřicí techniky a elektroniky je sestava tvořena těmito členy:

- Jednodeskový počítač

- Zvuková karta

- Výkonový zesilovač

- Středobasový reproduktor

- Měrííi mikrofony

- Čidlo teploty a vlhkosti

- Krokový motor s driverem

Schéma propojení jednotlivých členů je ukázáno na Obr. 4. Ústředním prvkem sestavy je jednodeskový počítač, na kterém probíhá jak měření, tak následné zpracování signálu a jsou do něj zapojeny ostatní periferie. První z nich je zvuková karta, která obstarává zvukové vstupy a výstupy a převod mezi analogovým a digitálním signálem. Do zvukové karty jsou dále zapojeny oba mikrofony a reproduktor s mezičlánkem v podobě výkonového zesilovače. Dalším připojeným zařízením je čidlo teploty a relativní vlhkosti, které slouží k záznamu těchto okrajových podmínek. Posledním prvkem, kterým se tato sestava zároveň liší od běžných komerčních sestav je doplnění části pro umístění vzorku o krokový motor a převod umožňující automatizovaný posun zadní stěny trubice a tím výrazné zefektivnění a rozšiřrení možností měření. 


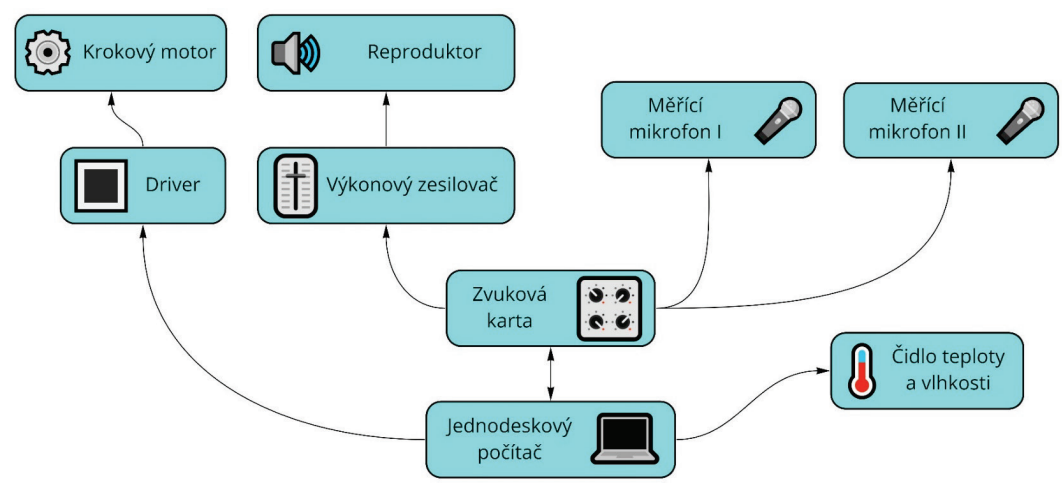

Obr. 4 Schéma zapojení jednotlivých členů měřící sestavy.

\section{Software}

Softwarová část měření byla napsána v programovacím jazyku Python [7]. Nejdůležitější použité knihovny a moduly jsou popsány v Tab. 2.

Tab. 2 Hlavní knihovny použité pro naprogramování měření a zpracování dat.

\begin{tabular}{cc}
\hline Knihovna & Stručný popis \\
\hline Scipy [8] & Ekosystém knihoven, jehož součástí jsou i knihovny pro zpracování digitálního signálu \\
Numpy [9] & Knihovna pro práci s rozsáhlými vektory a maticemi \\
Jackclient-python & Knihovna umožňující komunikaci se serverem JACK (Jack Audio Connection Kit) \\
[10] & a tedy přehrávání a nahrávání audio signálu s nízkou latencí a vysokou mírou kontroly. \\
Matplotlib [11] & Grafické výstupy měření \\
\hline
\end{tabular}

Pomocí těchto knihoven bylo možné kompletně implementovat měření i následný processing naměřených dat. Př́klad výstupu měření bez dodatečného post-processingu ukazuje Obr. 5.

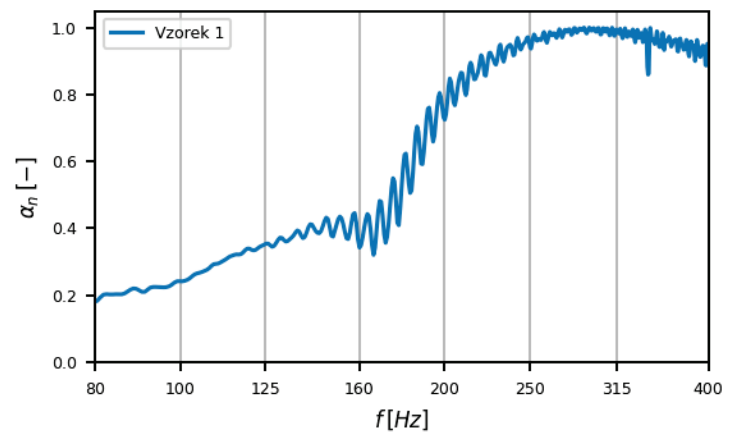

Obr. 5 Př́klad grafu závislosti činitele zvukové pohltivosti na frekvenci, změřená data bez dalšího processingu.

\section{DISKUSE}

Pro účely výzkumu chování akustických rezonátorů byl zhotoven prototyp impedanční trubice. Tato trubice vychází ze zásad uvedených v normě ČSN ISO 10534-2 [4], nicméně nad rámec této normy měření rozšiřuje o pohyblivou zadní stěnu. Díky tomu umožňuje souvislá měření pro více variant hloubky dutiny rezonátoru. Ta je 
jedním z hlavních návrhových parametrů většiny typů rezonátorů. Zásadním způsobem je tak rozšířena efektivita sběru dat pro širokou komparaci výsledků měření i pro porovnávání s výsledky získanými různými typy výpočtů. Dalším přínosem tohoto prototypu je zjištění, že je podobné měření možno realizovat za pomoci běžně dostupné spotřební elektroniky i měřícího hardwaru a že je tak možno s relativně nízkými náklady sestavit impedanční trubici vhodnou pro specifickou aplikaci. Měření rezonátorů představený prototyp přispívá i přizpůsobenou šířkou měřeného spektra a čtvercovým příčným průřezem. Výhodou je také možnost využít většinu hardwarového i softwarového řešení pro další jinak uzpůsobenou impedanční trubici.

Mezi nedostatky současného prototypu je nutno zahrnout poměrně úzké měřené spektrum a šum přítomný v naměřených datech. První nedostatek vychází převážně z metody samotné a jeho řešením je vytvoření druhé trubice o rozdílné geometrii. Č́stečné řešení také představuje přidání mezilehlého mikrofonu a díky tomu vyhodnocení ve dvou intervalech daných vzdáleností mikrofonů. Druhý problém je částečně řešitelný v rámci post-processingu. Jedním řešením je proložení vhodnou funkcí nebo splajnem, dalším pak filtrace dat pomocí Fourierovy transformace.

\section{ZÁV̌̌R}

Tento příspěvek představil vlastní řešení měření v impedanční trubici metodou přenosové funkce. Prezentovaný prototyp se i přes nedostatky uvedené $\mathrm{v}$ předchozí kapitole jeví jako dobře použitelný pro výzkum chování akustických rezonátorů v oblasti nízkých frekvencí. Díky specifickému řešení sestavy a zadní stěny trubice je možné v krátkém čase pořizovat relativně rozsáhlé a zároveň ucelené soubory dat, čehož bude využito v dalším výzkumu.

Další zdokonalení měření by mělo vést k rozšíření měřeného spektra pomocí třetího vloženého mikrofonu a zároveň k vyfiltrování šumu př́itomného ve vyhodnocených datech.

\section{Poděkování}

Př́spěvek vznikl za podpory projektů FAST-J-21-7481 "Teoreticko-experimentální analýza pohltivosti akustických rezonátorů" a FAST-J-21-7449 "Stanovení materiálového modelu kompozitního materiálu tvořeného cementovou matricí s rozptýlenými výztužnými organickými nebo anorganickými vlákny s ohledem na směr zatěžování".

\section{Použité zdroje}

[1] EVEREST, F. Alton a Ken C. POHLMANN. Master handbook of acoustics. 5th ed. New York: McGrawHill, 2009. ISBN 978-007-1603-331.

[2] ČSN EN ISO 354 (730535) Akustika. Měření zvukové pohltivosti v dozvukové místnosti. Praha: Český normalizační institut, 2003.

[3] ČSN ISO 10534-1 (730501) Akustika - Určování činitele zvukové pohltivosti a akustické impedance v impedančních trubicích - Č́st 1: Metoda poměru stojaté vlny. Praha: Český normalizační institut, 1999.

[4] ČSN ISO 10534-2 (730501) Akustika - Určování činitele zvukové pohltivosti a akustické impedance v impedančních trubicích - Část 2: Metoda přenosové funkce. Praha: Český normalizační institut.

[5] KUNDT, August. Ueber eine neue Art akustischer Staubfiguren und über die Anwendung derselben zur Bestimmung der Schallgeschwindigkeit in festen Körpern und Gasen. Annalen der Physik und Chemie. 1866, 203(4), 497-523. ISSN 00033804. Dostupné z: doi:10.1002/andp.18662030402

[6] COX, Trevor J. a Peter. D'ANTONIO. Acoustic absorbers and diffusers: theory, design and application. 2nd ed. New York: Taylor, c2009. ISBN 978-0-415-47174-9.

[7] VAN ROSSUM, G. a F. L. DRAKE. Python 3 Reference Manual. Scotts Valley, CA: CreateSpace, 2009. ISBN 1441412697.

[8] VIRTANEN, Pauli, Ralf GOMMERS, Travis E. OLIPHANT, et al. SciPy 1.0: fundamental algorithms for scientific computing in Python: fundamental algorithms for scientific computing in Python. Nature Methods. 2020, 17(3), 261-272. Dostupné z: doi:10.1038/s41592-019-0686-2

[9] HARRIS, Charles R., K. Jarrod MILLMAN, Stéfan J. VAN DER WALT, et al. Array programming with NumPy. Nature. 2020, 585(7825), 357-362. Dostupné z: doi:10.1038/s41586-020-2649-2

[10] JACK Audio Connection Kit (JACK) Client for Python [online]. 2020 [cit. 2021-11-14]. Dostupné z: https://jackclient-python.readthedocs.io/

[11] HUNTER, John D. Matplotlib: A 2D graphics environment: A 2D graphics environment. Computing in Science and Engineering. 2007, 9(3), 90-95. Dostupné z: doi:10.1109/MCSE.2007.55 